\title{
Employed family carers in Austria
}

The interplays of paid and unpaid work-beyond "reconciliation"

\author{
Karin Sardadvar · Ingrid Mairhuber
}

(C) The Author(s) 2018. This article is an open access publication.

\begin{abstract}
In this contribution, we investigate the relationships between paid and unpaid work in the lifeworlds of employed informal carers against the background of the Austrian long-term care regime. We pursue a twofold argument: On the one hand, we emphasize that combining paid and unpaid work currently poses serious difficulties for employed family carers in their everyday lives and impacts their current and future financial and social security. On the other hand, we argue that the relationships between employment and informal care are in fact not well understood by the common concepts of "reconciliation" or "work-life balance". These concepts are not able to explain the complexities of employed carers' lived realities and fail to adequately address the fundamental contradiction in the idea of a "reconciliation" of paid and unpaid work.
\end{abstract}

Keywords Family carers · Informal care $\cdot$ Long-term care regime

Reconciliation · Work-life balance

\section{Erwerbstätige pflegende Angehörige in Österreich}

Verhältnisse von bezahlter und unbezahlter Arbeit - jenseits von „Vereinbarkeit“

Zusammenfassung Der Beitrag analysiert die Beziehungen zwischen bezahlter Erwerbsarbeit und unbezahlter Betreuungsarbeit in der Lebenswelt pflegender Angehöriger vor dem Hintergrund des österreichischen Langzeitpflegeregimes. Wir dis-

K. Sardadvar $(\bowtie)$

WU Wien, Welthandelsplatz 1, 1020 Vienna, Austria

E-Mail: karin.sardadvar@wu.ac.at

I. Mairhuber

FORBA, Aspernbrückengasse 4/5, 1020 Vienna, Austria

E-Mail: mairhuber@forba.at 
kutieren zwei Hauptargumente: Auf der einen Seite unterstreichen die Ergebnisse, dass die Kombination von bezahlter und unbezahlter Arbeit derzeit unter erheblichen Schwierigkeiten erfolgt und negative Folgen für die gegenwärtige und zukünftige finanzielle und soziale Absicherung der Pflegenden mit sich bringt. Auf der anderen Seite argumentieren wir, dass das Verhältnis zwischen Erwerbs- und Pflegearbeit von den üblichen Konzepten der „Vereinbarkeit“ oder „Work-Life-Balance“ nicht adäquat erfasst wird. Diese Zugänge werden der Vielschichtigkeit der Bedeutungen von Erwerbs- und Pflegearbeit für pflegende Angehörige nicht gerecht und verschleiern den grundlegenden Widerspruch, der in der Idee einer „Vereinbarkeit" von bezahlter und unbezahlter Arbeit angelegt ist.

Schlüsselwörter Pflegende Angehörige · Informelle Pflege ·

Langzeitpflegeregime · Vereinbarkeit · Work-Life-Balance

\section{Introduction: The growing importance of employed family carers}

In social research, as well as policy-making, the situation of employed family carers began to be addressed remarkably late (Bouget et al. 2016; Kröger and Yeandle 2013). For years, it was largely neglected in mainstream research and policy on long-term care and the growing societal need for elderly care. Neither was it systematically included in the extensive social scientific and political discourses on work-life balance and the reconciliation of work and family. However, in light of growing female labor market participation, a prolonged stay in the labor market due to pension reforms, as well as ongoing demographic changes, the situation of employed family carers is becoming increasingly topical.

Recently, we can observe a growing awareness in social science and policymaking regarding the fact that reconciliation issues not only refer to childcare but also to long-term care (see, e.g., Bouget et al. 2016; Reuyß et al. 2012; Mairhuber 2014; Mairhuber and Sardadvar 2017b). Drawing on the definition of Kröger and Yeandle (2013, p. 13), by "informal" or "family" carers, we refer to "someone providing care based in a relational, affective or neighbourly context to a person with care needs arising from disability, long-term or terminal illness, or frailty in old age". Our focus lies on employed family carers, by which we mean informal carers who are active in the labor market.

In this contribution, we investigate the relationships between paid and unpaid work in the everyday lives of employed family carers. We analyze the tensions of their empirical lifeworlds in relation to the fundamental characteristics of the Austrian long-term care (LTC) regime (long-term care benefit, legal regulations, lack of care services). In so doing, we pursue a twofold argument: On the one hand, we emphasize that the combination of paid and unpaid work currently poses serious difficulties for employed family carers' individual everyday lives and impacts their financial and social security, both now and in the future. On the other hand, we argue that the relationships between paid and unpaid work are in fact not fully conveyed by the concepts of "reconciliation" or "work-life-balance". As we will show, these concepts are not able to explain the complexities of the relationship 
between employment and care work and fail to adequately address the fundamental contradiction in the idea of a "reconciliation" of paid and unpaid work.

After a short overview of the methodological approach, we analyze essential features of the Austrian LTC regime (see also Mairhuber and Sardadvar 2017a, 2017b). Based on qualitative case studies, we then examine different dimensions of the paid-unpaid-work-relationship in employed family carers' lifeworlds. We finish with conceptual and policy-oriented conclusions.

\section{Data and methodology: Policy analyses and empirical case studies}

In this paper, we present original findings from a research project in which we investigated the care arrangements and realities of employed family carers in the context of the Austrian LTC regime ${ }^{1}$. The project connected social policy analyses with qualitative sociological empirical research. The research included a detailed analysis of the relevant policy frameworks in Austria based on a literature review and analyses of legal provisions, six semi-structured expert interviews and, as a centerpiece of the empirical research, nine qualitative case studies (see also Mairhuber and Sardadvar 2017a, 2017b).

The experts interviewed represented public administration, NGOs, care service providers, and interest groups for informal carers. They covered the national level as well as two selected federal provinces (Vienna and Lower Austria), which differ in terms of regulation, urban or rural character, and actual care provision. The expert interviews aimed to complement the policy analyses and served to facilitate field access for the case studies.

The case studies aimed to understand the realities of the carers' lifeworlds, the care arrangements, the distribution of care work within the family and with professional staff, and the everyday relationships between paid work and unpaid care work. Interviews were conducted as open-ended qualitative interviews, supported by a guideline with sensitizing questions. They usually took place in peoples' homes and were conducted between May 2015 and January 2016. The case studies focused on the primary carer but included co-carers and/or care-receivers when applicable and possible. In two cases, the care-receivers took part in the interviews; in three cases, co-carers were interviewed as well.

The sample comprised different care arrangements. We refer to the people involved in these care arrangements (i.e., primary and co-carers, family members, care staff) as a care network. Cases varied, for example, with regard to the carers involved, the intensity of care needed and provided, and the living area, as well as the carers' gender, formal education level, employment status, and working times. The similarities and differences of the cases were selected in order to allow for methodological comparison. As this contribution presents only a part of the project findings

\footnotetext{
1 Project Erwerbstätige pflegende Angehörige in Österreich: Herausforderungen im Alltag und für die Politik, supported by funds of the Oesterreichische Nationalbank (Austrian Central Bank, Anniversary Fund, project number: 16049). For further publications of project findings, see Mairhuber and Sardadvar (2017a, 2017b).
} 
(see also Mairhuber and Sardadvar 2017a, 2017b), some of these case study characteristics, but not all, will be discussed as part of the findings. The cases included not only elderly relatives, which has so far been in the focus of much research on employed family carers, but also care for partners, siblings, and severely ill children (see Kröger and Yeandle 2013, p. 6).

For data analysis, we applied interpretive grounded theory coding methods based on the approach of Charmaz (2014). First, we conducted open coding on the single interviews; then we compared interviews within one case study (e.g., the primary and the co-carers' accounts). In a next step, we drew comparisons between cases and applied focused coding with regard to the central, analytically identified categories. In this process, we continuously contextualized the empirical findings with the results of the policy analyses.

\section{The Austrian long-term care regime: A gendered model of explicit familialism}

As in Europe in general (Colombo et al. 2011), in Austria, about $80 \%$ of care for the elderly or for people with disabilities is provided by informal family carers, most of whom are women (BMASK 2016, p. 37). Although the mean age of these family carers is high (Pochobradsky et al. 2005, p. 11), family carers of working age are common. In 2010, approximately 436,000 persons of working age provided family care. Of these, only $46 \%$ had a full-time job (45\% of whom were women) and $20 \%$ worked part-time ( $90 \%$ of whom were women), while the remaining part was not active in the labor market (70\% of whom were women) (Statistik Austria 2011, p. 33). This data suggests two things: Firstly, it is likely that there is a group of carers who have given up employment in order to provide informal care (see Schneider et al. 2013). Secondly, there is a substantial group of people for whom combining employment and family care is an issue. While there is a lack of comprehensive, current data on informal carers, in light of women's rising employment rates and men's growing participation in family care, a growth in the number of employed family carers can be expected (see Pochobradsky et al. 2005, p. 19).

In spite of the growing number of employed family carers, the non-employed female family carer is still the key element of the Austrian LTC regime (see also Mairhuber and Sardadvar 2017b). The main public care provision, the LTC benefit (Pflegegeld), a tax-funded universal non-means-tested benefit introduced in 1993, builds on the availability of unpaid or cheap care within the family. It was introduced to partly compensate for care-related additional expenses and to enable the person in need of care to buy care arrangements within or outside the family. Payments are granted to the care-receiver in seven categories, depending on the amount of care needed (see BMASK 2016, p. 7).

Although the amount of the LTC benefit is rather generous in international comparison (Da Roit et al. 2016, p. 148), it is not sufficient to ensure the provision of professional care or an adequate compensation for those providing informal care. In practice, care-related expenses often exceed the LTC benefit, leaving little to no room for paying for informal care. Hence, the Austrian LTC benefit builds on 
and thereby reinforces the availability of family care or care from the grey market (see Mairhuber 2000, pp. 179-181; Hammer and Österle 2003, pp. 44-47). Indeed, a growing irregular care market has developed in Austria, and in 2007, a legal basis for 24-hour support in private households was implemented (see Bachinger 2016).

Despite the importance of informal family care for the Austrian LTC regime, financial provisions are mainly aimed at the person in need of care. Direct supports for family carers are limited and have a narrow focus on providing practical information and enabling employment breaks. Measures put in place in the decades following the introduction of the LTC benefit largely support family carers to give up employment in order to provide care (e.g., coverage in health and pension insurance, or unpaid hospice leave; see Mairhuber and Sardadvar 2017a, 2017b).

When the LTC benefit was introduced, the provincial and federal governments also decided to expand care services. Indeed, an available and affordable offer of residential, semi-residential, and professional home care services is essential both to ensure the freedom of choice of the care-receiver and to combine employment and family care. Yet $53 \%$ of the recipients of LTC benefits are exclusively cared for by family carers (17\% use residential and nursing services, $5 \%$ rely on 24 -hour support, and $25 \%$ use professional home care services, often in combination with family care) (Rudda et al. 2008, p. 2). Although professional home care services have expanded in recent years-primarily in order to address the growing demand brought on by the ongoing demographic changes - their use is restricted by a lack of availability and flexibility due to an underfunding of the providers, and by the high costs for the users (Meier 2011, p. 78; Mairhuber and Sardadvar 2017a).

In 2014, a new measure in the Austrian LTC regime was introduced in two variants: care leave and part-time care leave, for a standard duration of three months. Taking leave is contingent upon an agreement with the employer and is compensated with a care leave allowance (Mairhuber and Sardadvar 2017a). As the first policy instrument to focus on carers rather than the persons in need of care, and explicitly addressing reconciliation issues, care leave can be seen as indicating a new approach in the Austrian LTC regime. However, as we have analyzed elsewhere (Mairhuber and Sardadvar 2017b), it has severe shortcomings with regard to carers' empirical needs, it leaves the framework conditions (e.g., a lack of professional home care services) unchanged, and its use, so far, is very limited (see BMASK 2016, p. 111).

To summarize, we conclude that the Austrian LTC regime conforms to the explicit familialism model (Leitner 2003, p. 358), which actively supports and in fact enforces the family's involvement in caring while at the same time lacking public and even market-driven care provision (Mairhuber and Sardadvar 2024b). The introduction of the care leave models may imply a step towards an optional familialism model (Leitner 2003, p. 359), as they offer the opportunity to (at least partly) provide family care without giving up employment. However, in contrast to the optional familialism model, which also aims for the freedom of choice not to provide informal care (Leitner 2003, p. 359), "the right not to care" (Lewis 1997, p. 173) is in practice not ensured in Austria (Kraus et al. 2011, p. 3).

Meanwhile, LTC regimes aimed at strengthening the caring function of the family automatically affect gender relations. As care in Austria is traditionally and empirically women's work, these policies not only support the family as such in its caring 
function but also enforce the caring role of women. Hence, the Austrian LTC policies can be characterized as a gendered model of explicit familialism, which reiterates the male breadwinner and female caregiver ideology (Mairhuber and Sardadvar 2017b; see also Leitner 2003, p. 354).

\section{Empirical evidence and lifeworld realities}

If the combination of employment and informal care is not facilitated on a structural level, as we have discussed in the previous section, then what does this mean for combining them on an individual level? In the following sections, we investigate how employed family carers organize and experience their work and live within the frameworks of and in tension with the Austrian LTC regime, and connect our findings to the current state of research. In the section Difficulties and impacts of combining paid and unpaid work, we argue that a "reconciliation" is hardly feasible at present, analyzing the difficulties and impacts of combining employment and informal care. In the section Dimensions of the relationship between paid and unpaid work, we argue that the empirical relationships between employment and informal care go beyond the idea of "reconciliation", presenting selected findings on how employed carers attribute meaning to their jobs in interaction with their care situations.

\subsection{Difficulties and impacts of combining paid and unpaid work}

\subsubsection{Irreconcilable: Paid work, unpaid work, and the other aspects of life}

International research has consistently shown that there are profound challenges, strains, and risks connected to providing informal care. Among them are health risks, psychological strain, a lack of recreational and personal time, and a risk of social isolation and family conflicts (see, e.g., Keck 2012, pp. 24-28; Kröger and Yeandle 2013 , p. 4). Austrian data indicates that about $77 \%$ of primary carers experience psychological strain, while $24 \%$ feel physically strained, $19 \%$ feel stressed by timepressure, and $11 \%$ feel financially burdened (BMASK 2016, p. 38).

For employed carers, conflicts between the demands of the two spheres add to these strains (see Keck 2012, p. 21). Our own research emphasizes that if "reconciliation" is supposed to refer to full-time employment, and to more than minimal involvement in informal care, it is largely only possible if there is a supporting network of co-carers and/or expensive 24-hour support due to the lack of affordable professional (home) care services. However, working part-time or taking leave does not solve the fundamental problems, either. In striving for a "reconciliation" or a "balance" of paid and unpaid work, carers make cuts in the remaining parts of their lives. They limit their personal lives, leisure time, and recreation to achieve a combination of paid and unpaid work. In the case studies, we identify this pattern across arrangements with differing care intensity. 
For example, Ms. Frankenberg ${ }^{2}$, a full-time employee who organized her exhusband's move to a nursing home, repeatedly used her annual leave for her care responsibilities. Ms. Wild, a full-time employee who cares for her father, is one of the few carers we met who takes one week of vacation each year. This, however-along with the fact that she can continue to work full-time-is only possible because she employs 24-hour support. Mr. Maier, a full-time employee in a management position, cared for his brother who was comatose in a nursing home. For more than two years, he went to see his brother at 6 a.m. for some time before going to work, and then again from 4-10 p.m. And Ms. Rauch, who lives in a household with her mother in need of care, explains: "I cannot sleep at my partner's house. If she [her frail mother] falls out of bed, then what will we do?" (c6, ip1).

Thus, the concept of "reconciling" employment and care work conceals that other parts of life fall by the wayside (see Jürgens 2009). Meanwhile, the idea of "balancing" work and life does not apply either, as carers possibly balance paid work and care work, but not necessarily the "life" aspects of the "work-life balance" (see Ungerson and Yeandle 2005). Hence, for some carers, "reconciliation" may work in the sense that they are able to provide care while remaining employed, but the question remains what price they pay for doing this.

\subsubsection{Employment as a financial necessity in a situation with increased costs}

Staying employed is, for many, a financial necessity and a prerequisite for their own social security, especially in old age. As we have argued regarding the LTC framework in Austria, the amount of the LTC benefit is usually insufficient to cover care costs and is targeted at the care-receiver but not the carer.

Unsurprisingly, then, families are confronted with additional costs that outstrip the LTC benefit. A typical pattern in the case studies is that the benefit is spent on parts of the care-related costs, while the remaining costs are then paid either out of the income (pension) of the person in need of care or, in fact, by the carer. For example, Ms. Wild employs 24-hour support for the care of her father, only a part of which is covered by the LTC benefit. The rest is paid from her own income. She says: "I provide all medical aids, so that I am able to finance this madness at all" (c5).

Therefore, in addition to the unpaid work they do, carers may also be facing increased expenditures. In these cases, carers may reduce their working hours and thus their income in order to have time to give care, while they are at the same time even more dependent on their income. For the same reason, some carers do not regard taking care leave as a feasible option (see Mairhuber and Sardadvar 2017b).

Especially in the case of middle-aged carers-a typical population providing informal care (Statistik Austria 2011, pp. 33-38)—we find that taking leave or even quitting employment can be particularly precarious, as they tend to fear that they will not to be able to return to the labor market at all and worry about the consequences for their pensions (see Mairhuber and Sardadvar 2017b; Kümmerling and Bäcker 2012).

\footnotetext{
2 All names have been changed.
} 
To conclude: As the LTC benefit is structurally limited, there is a trade-off between covering care-related costs, providing living expenses, and reimbursing the informal carers' unpaid work. While, according to the case studies, informal carers sometimes do receive some compensation from the LTC benefit receiver, some also use their own money to cover care-related costs. At the same time, however, some of them also reduce their working hours, and thus their incomes, labor market opportunities for their remaining employment years, and pensions, in order to provide care.

\subsection{Dimensions of the relationship between paid and unpaid work}

\subsubsection{Employment as a counterbalance to the care situation}

As has been shown so far, employed family carers are confronted with considerable difficulties with regard to their overall workload, quality of life, and social security. Against this background, it is even more remarkable that having a job can in fact support carers in being able to provide informal care in the first place. The case study findings highlight this meaning that carers ascribe to their jobs as a counterbalance to the care situation. For Ms. Wild, for example, going to work is "almost like vacation" (c5), adding that it "frees my mind in between" (c5).

Mr. Trost, who cared for his ill wife, refers to a similar argument when he explains why he took part-time leave for carers rather than full-time leave (see Mairhuber and Sardadvar 2017b). For him, too, the employment context counterbalanced the care situation, both during the acute care situation and after his wife had passed away. "Even now, it is good for me that I can pursue a regular job, that I am busy. Because at home, I get cabin fever" (c9).

In these cases, a life centered only on care-provision, albeit without "reconciliation" issues, appears in fact more burdensome than combining paid and unpaid work. But there is an ambivalence linked to this pattern: The care situation can spill over to the employment context, making it difficult to perform or concentrate at work (see, e.g., Jolanki et al. 2013; Keck 2012). Mr. Trost adds: "You have to perform at the office or at your workplace. [...] This was very hard for me" (c9).

These cases illustrate a central pattern in the data, in which having a working life supports or even enables carers to cope with the care work situation. This ties in to the finding of Jolanki et al. (2013, p. 63), according to which "[a]n important strategy for maintaining balance in one's life was refusing to give up work." While such a balance, as shown above, is in practice hard to achieve, the fact that carers still try to maintain both spheres is telling with regard to the importance it has for them to pursue paid work while providing care.

\subsubsection{Employment as a means to set limits to the care network}

Care arrangements often involve several family members. This can imply complex negotiations regarding who is in charge of caring and to what extent. In this context, we find a pattern in which employment becomes an important means for setting limits to co-carers' or care-receivers' demands (see also Keck 2012, p. 117). Am- 
bivalently, however, being employed does not at the same time automatically free carers from the responsibility of becoming a primary carer within the family setting.

Pursuing one's job can be a contested issue, one that is subject to constant negotiations within the care network. This is illustrated by the case of the sisters Ms. Rauch and Ms. Ruh. For Ms. Rauch, her employment in professional home care is one of the few options she sees for setting limits to the demands of her informal care network, i.e., her mother in need of care, who lives with her, and her sister, Ms. Ruh, who is retired and involved as co-carer. At the same time, Ms. Rauch's employment activity needs to be constantly defended and legitimated. The fact that she works, how much she works, what times she works, and when she will retire is a matter of ongoing negotiation with her sister and her mother. Although Ms. Rauch clearly is the primary carer, her sister and her mother criticize her for putting her job first.

Ms. Rauch works split shifts and receives her schedule on short notice. This makes it hard to make plans regarding care tasks. Ironically, however, the unpredictability of Ms. Rauch's working hours becomes helpful for her as a means of setting limits to her family's demands. Meanwhile, her shift patterns allow her to visit her mother during the day, thus facilitating a "reconciliation" in a narrow sense. But in view of her struggle to distance herself from the care setting, her working hours are very unfavorable.

Consequently, when we speak about reconciliation issues with Ms. Rauch in the interview, her answers do not refer to the compatibility of paid and unpaid work. Rather, she addresses the issue of setting limits to the care network. Hence, "reconciliation" in its usual sense, i. e., how she can manage paid and unpaid work in her everyday life, does not quite get to the point with regard to her lifeworld.

This observation has important methodological implications. Asking about "reconciliation" as researchers, for example in quantitative surveys, we may get answers that in fact refer to other aspects of the relationship between employment and informal care. Thus, the information gathered may be misleading if we do not succeed in asking questions that are able to capture people's relevant experiences. Hence, the comparatively new field of research on employed carers needs to be sensitive with regard to the concepts and terms it uses in order not to overlook the realities of the carers' lifeworlds and their attributions of meanings.

\section{Conclusions: The structural impossibility of individual reconciliation}

Within the Austrian LTC regime and its tensions with carers' lifeworlds, a combination of paid work and informal care is largely only possible with the support of a personal network and/or some working time reduction - and it is extremely stressful. But even in a part-time employment arrangement, to "reconcile" paid and unpaid work can require neglecting much of the "life" part of the "work-life balance" equation: the employed carers' personal lives, recreation, and wellbeing. As Ungerson and Yeandle (2005, p. 256) put it: "'Work-life balance' can transform into 'work-no-life' stasis." Thus, we agree with Leinonen and Sand that policies facilitating "reconciliation" between paid and unpaid work are not enough, as they 
disregard the "right to have time free from both paid and unpaid work" (Leinonen and Sand 2013, p. 173).

Therefore, reforms and changes are needed on at least two levels: the political framework of the Austrian LTC regime and the companies that actually employ the carers. On the political level, this requires the reorganization of the Austrian LTC regime away from a money-centered model based on a non-employed (female) carer and a (male) breadwinner to a model that supports the simultaneity of employment and family care. To this end, a significant expansion of available and affordable semi-residential and professional home care services as well as more direct supports for family carers are needed. These include an increase to the care leave allowance, organizational assistance (case and care management), and psychological support (see Mairhuber and Sardadvar 2017a, pp. 41-47).

Regarding the company level, there is high need to account for the fact that "family-friendly" policies do not only include childcare, and that carers' needs differ from those of parents (Kümmerling and Bäcker 2012; see also Mairhuber and Sardadvar 2017b). Concrete measures, which are not solely targeted at reducing working hours, have to be developed and implemented (see Kümmerling and Bäcker 2012; Auth et al. 2015; Reuyß et al. 2012; Keck 2012).

On the one hand, then, especially in light of the current features of the Austrian LTC regime, it is undoubtedly important to address the "reconciliation" of employment and informal care, not only on the political and company levels, but also within research and public discourse. On the other hand, however, it is insufficient or even misleading to address the issue within the scope of "reconciliation" or "work-life balance".

The term "reconciliation" suggests that the societal tensions in the relationship between paid and unpaid work can be, or are supposed to be, solved at the individual level. But as feminist theory has criticized in other contexts of unpaid work, in the dominating order of capitalist societies, the "reconciliation" of care work and employment is a "semantic trivialization of structural contradictions" (Jürgens 2009, p. 104, our translation) that ignores the "structural incompatibility of the current organization of 'work' and 'life"" (Kurz-Scherf 2007, p. 270, our translation) (see also, e.g., Aulenbacher 2013). Employment regulations and cultures are tightly connected to the full-time norm and the idea of the male "ideal worker" (Acker 1990) who is fully available for paid work and free from any constraints or needs situated in other life spheres. Thus, employed family carers try to "reconcile" the "irreconcilable". For women, the disadvantages (income and pension reductions, limitations with regard to labor market opportunities) of "reconciliation" attempts (employment interruptions and part-time employment) in fact accumulate during the course of their lives, as they are structurally and empirically likely to experience them both with regard to childcare and long-term care (see also Kümmerling and Bäcker 2012).

The "work-life balance" approach does not outweigh the limitations of the "reconciliation" approach either. Similarly, it has been criticized for focusing on the individual level, and for creating a dichotomy between "work" and "life" (see Jürgens 2009, pp. 165-175; Warhurst et al. 2008). Moreover, applied to combining paid work and care work, the work-life balance approach fails to address the other 
aspects of life (see Ungerson and Yeandle 2005). In addition to their conceptual shortcomings, the reconciliation and work-life balance approaches have mainly focused on families with small children (Kröger and Yeandle 2013, p. 4; Keck 2012, p. 12). Applied to long-term care, we find that the "reconciliation" of unpaid family care and employment is also an inadequate concept in the light of the empirical lifeworlds of unpaid family carers. Indeed, the relationship between employment and care work, from the point of view of the carers, is complex and ambivalent, going beyond what is captured by "reconciliation" or "balance".

Funding Open access funding provided by Vienna University of Economics and Business (WU).

Open Access This article is distributed under the terms of the Creative Commons Attribution 4.0 International License (http://creativecommons.org/licenses/by/4.0/), which permits unrestricted use, distribution, and reproduction in any medium, provided you give appropriate credit to the original author(s) and the source, provide a link to the Creative Commons license, and indicate if changes were made.

\section{References}

Acker, Joan. 1990. Hierarchies, jobs, bodies: a theory of gendered organizations. Gender \& Society 4:139-158.

Aulenbacher, Brigitte. 2013. Ökonomie und Sorgearbeit. Herrschaftslogiken, Arbeitsteilungen und Grenzziehungen im Gegenwartskapitalismus. In Gesellschaft - Feministische Krisendiagnosen, eds. Erna Appelt, Brigitte Aulenbacher, and Angelika Wetterer, 105-126. Münster: Westfälisches Dampfboot.

Auth, Diana, Daniela Brüker, Mirjam Dierkes, Simone Leiber, Sigrid Leitner, and Marina Vukoman. 2015. Wenn Mitarbeiter Angehörige pflegen: Betriebliche Wege zum Erfolg. Düsseldorf: Hans Böckler Stiftung.

Bachinger, Almut. 2016. 24-Stunden-Betreuung in Österreich - Die Nutzung migrantisierter Arbeitskraft. Vorzeigemodell oder Arbeitsausbeutung? Femina Politica 1:39-51. https://doi.org/10.3224/ feminapolitica.v25i1.23408.

BMASK. 2016. Österreichischer Pflegevorsorgebericht 2015. Wien: Bundesministerium für Arbeit, Soziales und Konsumentenschutz.

Bouget, Denis, Slavina Spasova, Bart Vanhercke, and European Social Policy Network (ESPN). 2016. Work-life balance measures for persons of working age with dependent relatives in Europe. A study of national policies. Brussels: European Commission.

Charmaz, Kathy. 2014. Constructing grounded theory, 2nd ed., London: SAGE.

Colombo, Francesca, Ana Llena-Nozal, Jérôme Mercier, and Frits Tjadens. 2011. Help wanted? Providing and paying for long-term care. Paris: OECD Publishing.

Hammer, Elisabeth, and August Österle. 2003. Welfare state policy and informal long-term care giving in Austria. Old gender divisions and new stratification processes among women. Journal of Social Policy 32:37-53. https://doi.org/10.1017/S0047279402006888.

Jolanki, Outi, Marta Szebehely, and Kaisa Kauppinen. 2013. Family rediscovered? Working carers of older people in Finland and Sweden. In Combining paid work and family care. Policies and experiences in international perspective, eds. Teppo Kröger, Sue Yeandle, 53-69. Bristol: Policy Press.

Jürgens, Kerstin. 2009. Arbeits- und Lebenskraft. Reproduktion als eigensinnige Grenzziehung. Wiesbaden: VS.

Keck, Wolfgang. 2012. Die Vereinbarkeit von häuslicher Pflege und Beruf. Bern: Huber.

Kraus, Markus, Thomas Czypionka, Monika Riedel, Esther Mot, and Peter Willemé. 2011. How European nations care for their elderly. A new typology of long-term care systems. Brussels: European Network of Economic Policy Research Institutions.

Kröger, Teppo, and Sue Yeandle. 2013. Reconciling work and care: an international analysis. In Combining paid work and family care. Policies and experiences in international perspective, eds. Teppo Kröger, Sue Yeandle, 3-22. Bristol: Policy Press. 
Kümmerling, Angelika, and Gerhard Bäcker. 2012. Carers@Work. Zwischen Beruf und Pflege: Betriebliche Maßnahmen zur Verbesserung der Vereinbarkeit von Erwerbstätigkeit und Pflegeverpflichtung. Duisburg: Universität Duisburg-Essen.

Kurz-Scherf, Ingrid. 2007. Soziabilität - auf der Suche nach neuen Leitbildern der Arbeits- und Geschlechterpolitik. In Arbeit und Geschlecht im Umbruch der modernen Gesellschaft. Forschung im Dialog, eds. Brigitte Aulenbacher, Maria Funder, Heike Jacobsen, and Susanne Völker, 269-284. Wiesbaden: VS.

Leinonen, Anu, and Ann-Britt Sand. 2013. Reconciling partner-care and paid work in Finland and Sweden: challenges and coping strategies. In Combining paid work and family care. Policies and experiences in international perspective, eds. Teppo Kröger, Sue Yeandle, 163-181. Bristol: Policy Press.

Leitner, Sigrid. 2003. Varieties of familialism. The caring function of the family in comparative perspective. European Societies 5:353-375. https://doi.org/10.1080/1461669032000127642.

Lewis, Jane. 1997. Gender and welfare regimes: further thoughts. Social Politics 4:160-177. https://doi. org/10.1093/sp/4.2.160.

Mairhuber, Ingrid. 2000. Die Regulierung des Geschlechterverhältnisses im Sozialstaat Österreich. Traditionen, Wandel und feministische Umbauoptionen. Frankfurt a. Main: Peter Lang.

Mairhuber, Ingrid. 2014. Vereinbarkeitsprobleme mit Zukunft? Erwerbsarbeit, Kinderbetreuung und Angehörigenpflege in Österreich. In Für sich und andere sorgen. Krise und Zukunft von Care in der modernen Gesellschaft, eds. Brigitte Aulenbacher, Maria Dammayr, 183-193. Weinheim: Beltz Juventa.

Mairhuber, Ingrid, and Karin Sardadvar. 2017a. Erwerbstätige pflegende Angehörige in Österreich: Herausforderungen im Alltag und für die Politik. Projekt-Teilbericht: Policy-Analyse und politische Empfehlungen. FORBA-Forschungsbericht 1/2017. Wien: FORBA.

Mairhuber, Ingrid, and Karin Sardadvar. 2017b. Pflegekarenz und Pflegeteilzeit in Österreich: Eine Neuausrichtung im Langzeitpflegeregime? Folgen, Potenziale und Grenzen einer Maßnahme zur ,Vereinbarkeit' von Erwerbsarbeit und Care. Femina Politica 2:47-61.

Meier, Irene. 2011. Status Quo und Regelungen zur Langzeitpflege in Österreich. In „Die Angehörigen wissen am besten was gut ist“, eds. Margarete Kreimer, Irene Meier, 59-82. Graz: Leykam.

Pochobradsky, Elisabeth, Franz Bergmann, Harald Brix-Samoylenko, Henning Erfkamp, and Renate Laub. 2005. Situation pflegender Angehöriger. Wien: Bundesministerium für soziale Sicherheit, Generationen und Konsumentenschutz.

Reuyß, Stefan, Svenja Pahl, Jürgen Rinderspacher, and Katrin Menke. 2012. Pflegesensible Arbeitszeiten. Perspektiven der Vereinbarkeit von Beruf und Pflege. Düsseldorf: Edition Sigma.

Da Roit, Barbara, Blanche Le Bihan, and August Österle. 2016. Cash-for-care benefits. In Long-term care reforms in OECD countries. Success and failures, eds. Christiano Gori, José-Luis Fernández, and Raphael Wittenberg, 143-166. Bristol: Policy Press.

Rudda, Johannes, Margarethe Fürstl-Grasser, and Max Rubisch. 2008. Neue Tendenzen der Pflegevorsorge in Österreich. Soziale Sicherheit 6:331-345.

Schneider, Ulrike, Birgit Trukeschitz, Richard Mühlmann, and Ivo Ponocny. 2013. "Do I stay or do I go?"- Job change and labor market exit intentions of employees providing informal care to older adults. Health Economics 22:1230-1249. https://doi.org/10.1002/hec.2880.

Statistik Austria. 2011. Vereinbarkeit von Beruf und Familie. Modul der Arbeitskräfteerhebung 2010. Wien: Statistik Austria.

Ungerson, Clare, and Sue Yeandle. 2005. Care workers and work-life balance: the example of domiciliary careworkers. In Work-lifebalance in the $21^{\text {st }}$ Century, ed. Diane M. Houston, 246-262. Houndmills: Palgrave MacMillan.

Warhurst, Chris, Doris Ruth Eikhof, and Axel Haunschild. 2008. Out of balance or just out of bounds? Analysing the relationship between work and life. In Work less, live more? Critical analysis of the work-life boundary, eds. Chris Warhurst, Doris Ruth Eikhof, and Axel Haunschild, 1-21. Basingstoke: Palgrave Macmillan.

Karin Sardadvar Mag. Dr., is post-doc researcher at the Institute for Sociology and Social Research, Vienna University of Economics and Business. Main research areas are work and gender, unpaid work, service work, care

Ingrid Mairhuber Mag. Dr., is senior researcher at the Working Life Research Centre (FORBA) in Vienna. Her main research areas are gender, labor market and social policies, reconciliation of paid employment and unpaid care work, as well as gendered life course 